\title{
PERORAL SUSCEPTIBILITY OF AEDES ALBIFASCIATUS AND CULEX PIPIENS COMPLEX MOSQUITOES (DIPTERA: CULICIDAE) FROM ARGENTINA TO WESTERN EQUINE ENCEPHALITIS VIRUS
}

Gabriela Aviles* Marta S. Sabattini** Carl J. Mitchell ${ }^{* * *}$

\begin{abstract}
AVILES, G. et al. Peroral susceptibility of Aedes albifasciatus and Culex pipiens complex mosquitoes (Diptera: Culicidae) from Argentina to western equine encephalitis virus. Rev. Saúde públ., S. Pau10, 24: 265-9, 1990.
\end{abstract}

\begin{abstract}
The transmission cycle of western equine encephalitis (WEE) virus in South America is unknown. A WEE virus strain was isolated from Aedes albifasciatus in Argentina during the WEE epizootic of 1982-83. Also, Culex pipiens from Argentina was reported to be able to transmit WEE virus experimentally, but other results indicate that Cx. pipiens from the USA is refractory to this virus. We determined the susceptibility of Argentina strains of Ae. albifasciatus and Culex pipiens complex mosquites to infection by WEE virus by the oral route. Adult females were fed on chicks infected with a WEE virus strain isolated in Cordoba Province, Argentina, or were fed on a blood/virus suspension. Each mosquito ingested between $10^{1.6}$ to $10^{6.4}$ vero cell plaque-forming units of virus. Each of 28 Ae. albifasciatus was positive for virus from the fourth day postfeeding, and there was evidence for virus replication. In contrast, $0 / 44 \mathrm{Cx}$. p. quinquefasciatus and only $1 / 15 \mathrm{Cx}$. p. pipiens was positive. Aedes albifasciatus is susceptible to infection by WEE virus and should be considered a potential vector of this virus in Argentina. Both subspecies of $\mathrm{C} x$. pipiens are refractory to peroral infection by WEE virus and probably do not play a role in the WEE virus cycle in Argentina.
\end{abstract}

KEYWORDS: Aedes, microbiology. Culex, microbiology. Encephalitis virus, western equine, pathogenicity.

\section{INTRODUCTION}

Western equine encephalitis (WEE) virus causes epidemics and epizootics in North and South America. In the Northern Hemisphere, Culex tarsalis and Aedes melanimon mosquitoes are important vectors ${ }^{7,8,15}$. In South America, severe aperiodic equine epizootics have been recognized since 1908 in the temperate zone of Argentina and Uruguay, although limited outbreaks in humans have been reported only in Southern Argentina ${ }^{16}$. In these areas the natural transmission cycle is unknown.

One hundred and forty-nine thousand mosquitoes collected in Santa Fe Province during the large WEE epizootic of 1982-83, yielded four WEE virus strains from $A e$. albifasciatus, Anopheles albitarsis, Mansonia species and Psorophora pallescens ${ }^{13}$. The mosquitoes were predominantly Ae. albifasciatus (42.8\%) and species of Culex (Culex) (34.4\%). In the south, where human cases had occurred, 474 mosquitoes $(70 \%$ Ae. albifasciatus and $30 \% \mathrm{Cx}$. species) were tested for virus with negative results.

Villa et al. ${ }^{17}$ reported that $C x$. pipiens from Buenos Aires Province, Argentina, were able to transmit an Argentine strain of WEE virus under experimental conditions. The virus strain had undergone several laboratory passages in guinea pigs and chick embryos, and a high dose of virus in the blood meal was used. In contrast, attempts to experimentally transmit California and Washington strains of WEE virus by $C x$. pipiens in the USA were unseccessful ${ }^{15}$. Subsequent studies showed that USA strains of $C x$. pipiens were essentially refractory to peroral infection with WEE virus ${ }^{8,9}$.

Culex pipiens is represented by two subspecies in Argentina; $C x . p$. quinquefasciatus occurs in Central and Northern Argentina and $C x$. p.pipiens in Southern Argentina. Hybrids are present in the zone where the subspecies overlap ${ }^{2,10}$. The objec-

Research fellow of CONICET (Consejo Nacional de Investigaciones Científicas y Tecnicas), Argentina.

* Instituto of Virology "Dr. J. M. Vanella", Faculty of Medical Science, University of Córdoba, Estafeta 32 , Córdoba, 5000 Argentina.

* * Division of Vector-Borne Infectious Diseases, Center for Infectious Diseases, Centers for Disease Control, Public Health Service, U. S. Department of Health and Human Services - P. O. Box 2087, Fort Collins, Colorado 80522 - USA. 
tive of the present work was to determine whether Argentine $C x$. pipiens complex mosquitoes and Ae, albifasciatus were susceptible to infection by WEE virus by the oral route.

\section{MATERIALS AND METHODS}

\section{WEE virus strain:}

The Cba CIV 180 strain was isolated from the brain of a sick horse in Cordoba Province during the epizootic of 1982-83 and had undergone three passages in suckling mouse brains. The virus stock was made with mouse brains harvested 24 to $48 \mathrm{~h}$ after intracerebral inoculation and was prepared as a $10 \% \mathrm{~W} / \mathrm{V}$ suspension.

\section{Mosquitoes:}

Adult Ae. albifasciatus females were captured by mechanical aspirator from human bait on a farm near Córdoba City ( $\left.31^{\circ} 22^{\prime} \mathrm{S}, 64^{\circ} 14^{\prime} \mathrm{W}\right)$, Córdoba Province, Argentina. Attempts to colonize this species in the laboratory were unsucessful.

Female $C x$. p. quinquefasciatus of the second laboratory generation were used at 14 days of age. They originated from a single oviposition from females collected in the urban area of Córdoba City. Culex p.pipiens of the second and the third generations came from two ovipositions of females collected in Puerto Madryn, (42 $\left.50^{\circ} \mathrm{S}, 65^{\circ} 05^{\prime} \mathrm{W}\right)$, Chubut Province, Argentina, and were used as 5-to 10-day old females. The subspecies were determined by examining the male genitalia ${ }^{1}$ of thirteen specimens from each colony. No intermediates between pipiens and quinquefasciatus were found.

\section{Experimental Design:}

Mosquitoes were infected by feeding on 1-to $12-$ day-old viremic chicks previously inoculated subcutaneously with approximately $10^{3.0}-10^{3.7}$ vero cell culture plaque-forming units (PFU) of virus.

Since few Ae. albifasciatus fed, an additional attempt was made to expose mosquitoes to infection by the oral route by using an artificial feeding technique. A heparinized-blood/virus suspension was prepared by mixing $0.5 \mathrm{ml}$ of the stock virus (titer $\left.10^{8.0} \mathrm{PFU} / 0.1 \mathrm{ml}\right), 3 \mathrm{ml}$ of normal guinea pig blood, and $1.5 \mathrm{ml}$ of Media 199. The suspension contained $10^{5.7} \mathrm{PFU} / 5 \mu \mathrm{l}$ and the mosquitoes were allowed to feed during a 2-h period. Culex pipiens mosquitoes were starved $24 \mathrm{~h}$ before the experiments were initiated.

Mosquitoes were allowed to feed on viremic chicks during a 9-to 15 -h period at 10 to $24 \mathrm{~h}$ postinoculation. Serum specimens were taken from the chicks preexposure and postexposure. Blood was diluted $1: 10$ in a heparinized diluent and centri- fuged at $4^{\circ} \mathrm{C}$ and $750 \times \mathrm{g}$ for 30 minutes. Supernatants were frozen at $-80^{\circ} \mathrm{C}$ until tested for virus. A group of freshly fed mosquitoes also was frozen at $-80^{\circ} \mathrm{C}$ until tested for virus and used as the sample for the first day of incubation.

The remaining fed mosquitoes were incubated in a secure room inside a laboratory with level 2 biosafety (Biosafety in Microbiological and Biomedical Laboratories, 1984), at $26^{\circ} \mathrm{C}$ maximum$21^{\circ} \mathrm{C}$ minimum for Ae. albifasciatus, $30^{\circ} \mathrm{C}$ maximum $-24^{\circ} \mathrm{C}$ minimum for $C x, p$. quinquefasciatus and $26^{\circ} \mathrm{C}$ maximum $-15^{\circ} \mathrm{C}$ minimum for $\mathrm{Cx}$. p. pipiens, in a humid atmosphere and at natural photoperiods with at least $11 \mathrm{~h}$ of full light.

Samples of 1 to 11 mosquitoes were frozen on different days of incubation for subsequent titration. They were triturated individually with $1 \mathrm{ml}$ of diluent (Media 199, 20\% fetal calf serum and gentamicin $5 \mathrm{mg} \%$ ). Suspensions were centrifuged at $11,400 \times \mathrm{g}$ for 30 minutes at $4^{\circ} \mathrm{C}$ and supernatants were serially diluted in the same diluent and inoculated in $0.1-\mathrm{ml}$ volumes into $\mathrm{C} 176$ vero cell culture under double agar overlay5. The second agar overlay was added after $48 \mathrm{~h}$, and the cell cultures were examined for 3 days and characteristic plaques were counted. Virus titers of mosquitoes are expressed as $\mathrm{PFU} / \mathrm{mosquito}$. The infection rate of mosquitoes was established taking into account the number of infected mosquitoes and the total number tested from days 3 and 4 to day 21 postinfection.

\section{RESULTS}

Culex $p$. quinquefasciatus fed readily and survived well. Ae. albifasciatus and $C x . p$. pipiens showed low feeding rates and high mortality. A total of $41 \mathrm{Ae}$. albifasciatus, $48 \mathrm{Cx}$. p. quinquefasciatus, and $21 \mathrm{Cx}$.p.pipiens were tested (Table 1).

\section{TABLE 1}

Feeding rates and survival of Aedes albifasciatus and two subspecies of Culex pipiens during infection experiments with WEE virus.

\begin{tabular}{lcccc}
\hline $\begin{array}{l}\text { Mosquito } \\
\text { species/ } \\
\text { subspecies }\end{array}$ & $\begin{array}{l}\text { No. of } \\
\text { feeding } \\
\text { trials }\end{array}$ & $\begin{array}{l}\text { Number } \\
\text { exposed }\end{array}$ & $\begin{array}{l}\text { Number } \\
\text { fed }\end{array}$ & $\begin{array}{l}\text { Number } \\
\text { survived } \\
\text { and } \\
\text { tested } \\
\text { for virus }\end{array}$ \\
\hline $\begin{array}{l}\text { Aedes albifas- } \\
\text { ciatus }\end{array}$ & 13 & 651 & 86 & 41 \\
$\begin{array}{l}\text { Cx. p.quinque- } \\
\text { fasciatus }\end{array}$ & 1 & 60 & 52 & 48 \\
Cx. p. pipiens & 2 & 85 & 25 & 21 \\
\hline
\end{tabular}

Virus titers of the infective meals (chick bloods and viral suspension) and individual $A e$. albifasciatus titers are shown in Table 2. Ae, albi- 
fasciatus sampled on the first day had virus titers of $10^{3.9}$ to $10^{6.6} \mathrm{PFU} / \mathrm{mosquito}$. All Ae. albifasciatus tested after the fourth day were positive with virus titers of $10^{3.3}$ to $10^{6.7} \mathrm{PFU} /$ mosquito.

\section{TABLE 2}

Cba CIV 180 WEE virus titers in the infective meals and in individual Aedes albifasciatus mosquitoes infected by peroral route.

\begin{tabular}{|c|c|c|c|c|c|c|c|c|c|}
\hline \multirow{2}{*}{$\begin{array}{l}\text { Infective meal } \\
\text { virus pre-post } \\
\text { exposure } \\
\text { period (log } \\
\text { PFU } / 5 \mu 1)\end{array}$} & \multicolumn{9}{|c|}{$\begin{array}{l}\text { Virus titers (log PFU/mosquito) of } \\
\text { individual mosquitoes per day of } \\
\text { extrinsic incubation }\end{array}$} \\
\hline & 1 & 2 & 4 & 5 & 6 & 8 & 9 & 11 & 13 \\
\hline $1.6-2.7$ & 4.4 & & $\begin{array}{l}5.3 \\
6.7 \\
6.0 \\
4.6\end{array}$ & & & $\begin{array}{l}6.7 \\
5.8\end{array}$ & & & \\
\hline $3.9-3.9$ & 3.9 & & $\begin{array}{l}5.5 \\
5.7 \\
6.6\end{array}$ & & & & & & \\
\hline $4.1-4.4$ & & & & $\begin{array}{l}6.3 \\
6.5\end{array}$ & & & & & $\begin{array}{l}4.5 \\
4.5 \\
5.6\end{array}$ \\
\hline
\end{tabular}

$\begin{array}{lll}4.7-4.9 & & 4.5 \\ & & 5.5 \\ 5.0-5.4 & 5.3 & 3.5 \\ & & 5.9\end{array}$

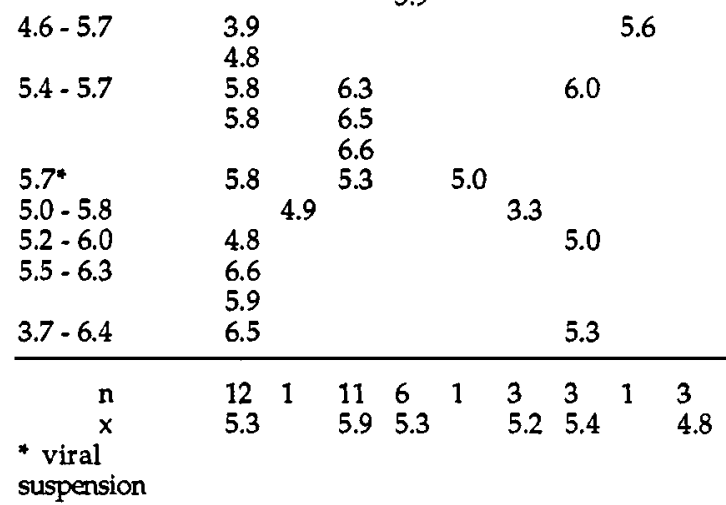

Culex $p$. quinquefasciatus were fed an infective meal that titered $10^{4.3}$ to $10^{4.5} \mathrm{PFU} / \mathrm{ml}$. Four freshly-fed females contained $10^{2.2}$ to $10^{2.5} \mathrm{PFU/}$ mosquito immediately after feeding. Thereafter, none of 44 females tested on days 3 through 20 postfeeding were positive for virus. Culex $p$. pipiens were fed on an infective meal that titered $10^{5.5}$ to $10^{7.5} \mathrm{PFU} / \mathrm{ml}$. Six freshly-fed females contained $10^{3.1}$ to $10^{4.1} \mathrm{PFU} /$ mosquito immediately after feeding. Thereafter, only 1 of 15 mosquitoes tested on days 4 through 21 postfeeding was positive for virus. The positive female was tested on day 4 postfeeding and contained $10^{2.1}$ PFU of virus.

Using an estimated blood meal volume of $5 \mu \mathrm{l}$, it was calculated that each Ae. albifasciatus ingested between $10^{1.6}$ to $10^{6.4} \mathrm{PFU}$, each $C x$. p. quinquefasciatus between $10^{2.0}$ to $10^{2.2} \mathrm{PFU}$, and each Cx. p. pipiens between $10^{3.1}$ to $10^{5.1} \mathrm{PFU}$ of virus.

\section{DISCUSSION}

Virus titers in freshly-fed mosquitoes (day one of incubation) represent remmants of ingested virus and correlate with titers of the infective meals. The results of Villa et al. ${ }^{17}$ suggested that WEE virus could infect and be transmitted by $C x$. pipiens after ingestion of large doses of virus $\left(10^{7.3}\right.$ $\mathrm{LD}_{50} / 5 \mu \mathrm{l}$ for 3-week-old mice). According to our results, Argentinian $C x$. pipiens of both subspecies have a low capacity to become infected with Argentinian WEE virus, and the infection threshold is $>10^{3}$ PFU for $C x$. p. quinquefasciatus and $>10^{2}$ PFU for $C x$. p. pipiens. These titers are sufficient to infect known vector species of Culex and Aedes ${ }^{4,6}$. The lack of isolations of WEE virus from Culex in nature during WEE epizootics in Argentina, combined with our results, suggest that $C x$. pipiens does not play an important role in the WEE virus cycle in Argentina. Our results concerning the vector competence of $C x$. pipiens for WEE virus agree with those from the USA ${ }^{8,9,15}$.

The demonstrated susceptibility of Ae. albifasciatus to infection with WEE virus by the oral route is further evidence for considering this species to be a potencial vector of WEE virus in Argentina. Aedes albifasciatus has been found naturally infected and it was an abundant mosquito during the $1982-83$ epizootic ${ }^{13}$. This mosquito feeds mainly on mammals, especially bovines and equines $11,12,14$. It has been suggested that Ae. albifasciatus may serve as a vector in a WEE virus transmission cycle involving the European hare (Lepus europaeus) in Argentina ${ }^{14}$. This would correspond to a similar cycle involving Aedes melanimon and Lepus californicus in California ${ }^{7}$. Further incrimination of $\mathrm{Ae}$. albifasciatus as a vector of WEE virus must await more definitive experiments on vector competence that include determiration of transmission efficiency. This is difficult to accomplish because the species has not been colonized, and it is difficult to get field-collected specimens to feed, survive, oviposit, and refeed in the laboratory.

\section{ACKNOWLEDGMENTS}

To Drs. Mireya de Brewer, Biol. Liliana Buffa and Biol. Walter Almiron, for their assistance in identifying Culex pipiens complex mosquitoes to subspecies. To the Centre National Patagonico (CONICET), especially to Dr. Jose Luis Garrido for facilitating our work in Chubut Province, and for the economic assistance to CONICET, CONICOR (Consejo de Investigaciones de Córdoba) y SE.NA.SA. (Servicio Nacional de Sanidad Animal). 
AVILES, G. et al. Suscetibilidade por via oral dos mosquitos Aedes albifasciatus e do complexo Culex pipiens (Diptera: Culicidae) da Argentina ao vírus da encefalite equina tipo oeste. Rev. Saúde públ., S. Paulo, 24: 265-9, 1990.

RESUMO: Desconhece-se o ciclo de transmissão da encefalite equina tipo oeste (WEE) na América do Sul. Uma cepa do vírus foi isolada na Argentina, durante a epizootia de 1982-1983, a partir de Aedes albifasciatus. Sob o ponto de vista experimental, o Culex pipiens da Argentina revelou-se capaz de transmitir o vírus WEE, porém outros resultados têm indicado que o $C x$. pipiens dos Estados Unidos é refratário a esse vírus. Assim, procurou-se determinar a suscetibilidade de cepas argentinas de Ae. albifasciatus e complexo Culex pipiens, à infecção do vírus WEE por via oral. As fêmeas adultas foram alimentadas em pintos infectados com cepa do vírus isolada na Província de Córdoba, Argentina, ou então alimentadas em suspensão do virus e sangue. Cada mosquito ingeriu entre $10^{1,6}$ e $10^{6,4}$ unidades virals formadoras de placas de cultura de célula ("vero cell"). Cada um dos 28 Ae. albifasciatus mostrou-se a partir do quarto dia pós-prandial e houve evidência de replicaçăo viral. Em contraposição, $0 / 44 C x$. p. quinquefasciatus e apenas $1 / 15 \mathrm{Cx}$. p. pipiens revelou-se positivo. Aedes albifasciatus é suscetível à infecção pelo vírus WEE e deveria ser considerado vetor potencial desse agente na Argentina. Ambas subespécies de $C x$. pipiens são refratárias à infecção por via oral e provavelmente não desempenham papel do ciclo do vírus WEE na Argentina.

DESCRITORES: Aedes, microbiologia. Culex, microbiologia. Vírus da encefalite eqüina ocidental, patogenicidade.

\section{REFERENCES}

1. BARR, A. R. The distribution of Culex p. pipiens and C.p.quiquefasciatus in North America. Amer. J. trop. Med. Hyg., 6: 153-65, 1957.

2. BREWER, M.; BUFFA, L.; ALMIRON, W. Culex pipiens quinquefasciatus y Culex pipiens pipiens (Dipt.; Culicidae) en Córdoba, Argentina. Rev. per. Ent., 29: 69.72, 1987.

3. CENTERS FOR DISEASE CONTROL. NATIONAL INSTI TUTES OF HEALTH. Biosafety in microbiological and biomedical laboratories 1984. Atlanta, Ga, 1984. (PHS Publication N. (CDC) 84-8395).

4. CHAMBERLAIN, R. W. \& SUDIA, W. D. The North American arthropodbome encephalitis viruses in Culex tarsalis Coquillet. Amer. J. Hyg., 66: 151-9, 1957.

5. CONTIGIANI, M. S. \& SABATTINI, M. S. Virulencia diferencial de cepas de virus Junin por marcadores biológicos en ratones y cobayos. Medicina, Buenos Aires, 37: 244-51, 1977.

6. HARDY, J. L. The ecology of Western Equine Encephalitis virus in the Central Valley of California, 1945-1985. Amer. J. trop. Med. Hyg., 37 (Suppl.): 18S-32S, 1987.

7. HARDY, J. L. \& BRUEN, J. P. Aedes melanimon as a vector of WEE virus in California. Proc. Calif. Mosquito control Ass., 42: 36, 1974.

8. HARDY, J. L.; REEVES, W. C.; BRUEN, J. P.; PRESSER, S. B. Vector competence of Culex tarsalis and other mosquito species for Western Equine Encephalomyelitis virus. In: Kurstak, E., ed. Arctic and tropical arboviruses. New York, Academic Press, 1979. p. 157-71.

9. HOUK, E. J.; KRAMER, L. D.; HARDY, J. L.; PRESSER, S. B. An interspecific mosquito model for the mesenteronal infection barrier to Westem Equine
Encephalomyelitis virus (Culex tarsalis and Culex pipiens). Amer. J. trop. Med. Hyg., 35:632-41, 1986.

10. MITCHELL, C. J.; DARSIE, R. F.; MONATH, T. P. Occurrence of autogenous Culex pipiens Linnaeus, 1758, (Diptera: Culicidae) in Argentina and notes on distribution of the complex. Mosquito System., 16:308-16, 1984.

11. MITCHELL, C. J.; DARSIE, R. F.; MONATH, T. P.; SABATTINI, M. S.; DAFFNER, J. F. The use of an animal-baited net trap for collecting mosquitoes during Westem Equine Encephalitis investigations in Argentina. J. Amer. Mosquito control Ass. 1:437, 1985.

12. MITCHELL, C. J.; MONATH, T. P.; SABATTINI, M. S.; CROPP, C. B.; DAFFNER, J. F.; CALISHER, C. J.; JAKOB, W. L.; CHRISTENSEN, H. A. Arbovinus investigations in Argentina. II. Arthropod collections and virus isolations from mosquitoes, 1977-80. Amer. J. trop. Med. Hyg., 34:945-55, 1985.

13. MITCHELL, C. J.; MONATH, T. P.; SABATTINI, M. S.; DAFFNER, J. F.; CROPP, C. B.; CALISHER, C. H.; DARSIE, R. F.; JAKOB, W. L. Arbovinis isolations from mosquitoes collected during and after the 1982-1983 epizootic of Westem Equine Encephalitis in Argentina. Amer. J. trop. Med. Hyg., 36:107-13, 1987.

14. MTCHELL, C. J.; MONATH, T. P.; SABATTINI, M. S.; CHRISTENSEN, H. A.; DARSIE Jr., R. F.; JAKOB, W. L.; DAFFNER, J. F. Host-feeding patterns of Argentine mosquitoes (Diptera: Culicidae) collected during and after an epizootic of Western Equine Encephalitis. J. med. Ent., 24:260-7, 1987.

15. REEVES, W. C. \& HAMMON, W. Mc D. Epidemiology of the arthropod-borne viral encephalitides in 
Kern County, California, 1943-1952. Berkeley, University of Califomia Press, 1962. (Univ. Calif. Publ. Public Hlth., v. 4).

16. SABATTINI, M. S.; MONATH, T. P.; MITCHELL, C. J.; DAFFNER, J. F.; BOWEN, G. S.; PAULI, R.; CONTIGIANI, M. S. Arbovirus investigation in Argentina, 1977-80. I. Historical aspects and description of study sites. Amer. J. trop. Med. Hyg., $34: 937-44$, 1985 .
17. VILLA, L. J.; BLND de PEREZ, C.; MUNIZ VEGA, A. E. Transmisión del virus de encefalomielitis equina oeste de pollito a pollito por el Culex pipiens (Say). Investigaciones ganaderas, 14 (11): 97-103, 1962.

Received in 26/4/1990 Accepted in $1816 / 1990$ 